\title{
EXPERIMENTAL STUDY OF LIGHTWEIGHT REINFORCED CONCRETE HOLLOW ONE-WAY SLABS WITH PARTIALLY REPLACEMENT BY RECYCLED COARSE AGGREGATE
}

\author{
BARAa T. KAMEL ${ }^{*}$, MuYasser M. Jomaa' ${ }^{2}{ }^{* *}$, and Hosam A. AlazZawi ${ }^{*}$ \\ *College of Engineering, University of Kirkuk, IRAQ \\ ***llege of Engineering, University of Tikrit, IRAQ
}

(Accepted for Publication: December 8, 2020)

\begin{abstract}
The technological development, together with the society tendency to replacing old methods through the applications of the construction materials with high efficiency, low costs and high durability by using structural thermal insulation systems, intends to increase the design age of the facilities and reduce energy consumption. Therefore, the study of light weight hollow concrete panels, becomes an important scientific goal in structural engineering. This study aimed to use lightweight and recycled materials as coarse aggregates to produce environmentally friendly concrete. Thirty-nine specimens of hollow one-way reinforced panels with dimensions $(800 \times 400 \times 100) \mathrm{mm}$ have been prepared and classified into four groups (3 panels used as reference specimens and 9 panels per each group). Claystone (ponza), thermostone aggregates, waste rubber pieces from used tires and polystyrene (cork) with volumetric replacement ratios of $(25,50$ and 75$)$ percentages of the normal aggregate were used respectively. The mechanical properties of the concrete mixtures were studied by preparing (60) samples of cylinders and prisms. The test results indicated a decrease in the mechanical properties with an increase in the percentage of lightweight coarse aggregate (25, 50 and 75 percentages). Compressive strength, tensile strength, flexural resistance and the density of the concrete test results were (10.66 - 38.44) MPa, (1.122 3.969) MPa, (3.606 - 10.467) MPa and (1665.5- 2426.41) $\mathrm{kg} / \mathrm{m}^{3}$ respectively, while the ductility index in the range of (1.61-3.33). The results showed that using lightweight aggregate contributed in reducing the dead load of the proposed specimens, in addition, the best concrete mixture was that replaced by $75 \%$ of the normal aggregate with thermostone and rubber materials, as it achieved low density and acceptable compressive strength $\left(1755.8 \mathrm{~kg} / \mathrm{m}^{3}, 15.47 \mathrm{MPa}\right)$ and $\left(1835.5 \mathrm{~kg} / \mathrm{m}^{3}, 15.47 \mathrm{MPa}\right)$ respectively. The internal voids ratio of the sample was adopted with a total ratio of $20 \%$ of the total size of the standard sample. The results of the bending moment capacity test of the hollow panels for failure load values ranged between $(23.704-9.259) \mathrm{kN}$ for the adopted group specimens compared with the reference specimen which achieved a maximum failure load of $(\mathbf{2 4 . 8 1 0}) \mathrm{kN}$.
\end{abstract}

KEYWORDS: Coarse Aggregate, Lightweight Aggregate, One-Way Slabs, Voided and hollow slabs.

\section{INTRODUCTION}

$\mathbf{L}$ ightweight concrete LWC is a special material which has a dry density less than (2000) $\mathrm{kg} / \mathrm{m}^{3}$. It can be produced by replacing a part of the aggregates or all the typical aggregates by lightweight materials. The natural lightweight aggregate of low density, pumice for instance, can be applied to produce lightweight concrete (Amato et al., 2011). Using

baraakamel@uokirkuk.edu.iq; muyasserjomaah@tu.edu.iq; dr.husamdaham@tu.edu.iq

${ }^{2}$ Corresponding author: College of Engineering, University of Tikrit, Tikrit, Iraq 
partially lightweight coarse aggregate as a replacement aggregate in the mixture can produce lightweight concrete which has low density (Jomaa'h et al. 2019). The lightweight concrete can be classified into three types according to its manufacturing method. These three main types are, No-fines concrete, Aerated concrete, and Lightweight aggregate concrete, LWAC. Many research works were conducted to study the behavior of these types (Narayana and Ramamurthy, 2000). The properties of LWAC depend mainly on the lightweight aggregate used in the mixture. Obviously, the lightweight aggregates rely on its chemical as well as physical and mechanical properties to improve the overall concrete quality. Production method is another factor can lead to develop the properties of the concrete. The concrete density and its compressive strength are the main parameters to consider during the design of the lightweight concrete. Therefore, the lightweight concrete is widely used these days because of its many advantages, low density, and acceptable strength as examples. The compressive strength of LWAC can exceed $35 \mathrm{MPa}$, and in limited cases can even achieve much more this value up to $69 \mathrm{MPa}$ (Walraven, 2002). The second part of present paper deals with using the recycled materials as a lightweight aggregate. The lightweight recyclable materials, such as tire rubber, can be a vital solution since they can reduce the concrete density by partially replacing coarse aggregates. In addition, using recycled aggregates can also save energy and decrease the cost of production due to using exciting materials. In this research, thirty-nine specimens were tested experimentally. The samples were with lightweight aggregates and some of them with recycled materials. The recycling of the lightweight aggregates used in the tests was applied by changing the volumetric ratio of the recycled to conventional aggregates. The obtained results from this study were mainly included, concrete density, compressive strength, modulus of rupture and splitting. The optimum material properties and energy saving will be described. The main objective of this research is to investigate experimentally the effect of using different types of aggregate on the hollow one way slabs.

\section{MATERIALS PROPERTIES}

\subsection{Cement}

The cement type used in this study is Ordinary Portland Cement (type I) which is made by Bazian Cement Factory, (Sulymania, Iraq). The physical and chemical properties obtained from the analysis and tests are presented in Tables 1 and 2 respectively. All the tests were done at Kirkuk National Laboratory.

baraakamel@uokirkuk.edu.iq; muyasserjomaah@tu.edu.iq; dr.husamdaham@tu.edu.iq 
Table (1): Physical properties of cement

\begin{tabular}{|c|c|c|}
\hline Physical Properties & Test Results & $\begin{array}{l}\text { Limit of Iraqi Specification No. } \\
5 \backslash 1984\end{array}$ \\
\hline Specific surface area & $351 \mathrm{~m}^{2} / \mathrm{kg}$ & $(230 \mathrm{~m} 2 / \mathrm{kg})$ \\
\hline (Blaine method) (m2/kg) & & lower limit \\
\hline \multirow{2}{*}{\multicolumn{3}{|c|}{$\begin{array}{c}\text { Setting time } \\
\text { (vacate apparatus) }\end{array}$}} \\
\hline & & \\
\hline Initial setting: & $3 \mathrm{hrs} . \quad 7 \mathrm{~min}$ & Not less than $45 \mathrm{~min}$ \\
\hline Final setting: & $5 \mathrm{hrs} .25 \mathrm{~min}$ & Not more than 10 hrs. \\
\hline \multicolumn{3}{|l|}{ Compressive strength (MPa) } \\
\hline at 3-day & $21.9 \mathrm{MPa}$ & Not less than $15 \mathrm{MPa}$ \\
\hline at 7-day & $28.6 \mathrm{MPa}$ & Not less than $23 \mathrm{MPa}$ \\
\hline
\end{tabular}

Table (2): Chemical properties of cement used

\begin{tabular}{|c|c|c|}
\hline Oxides Composition & Content ( \%) & Limit of Iraqi Specification No.5\1984 \\
\hline $\mathrm{CaO}$ & 61.45 & - \\
\hline $\mathrm{Al} 2 \mathrm{O} 3$ & 4.87 & - \\
\hline $\mathrm{SiO} 2$ & 20.75 & - \\
\hline $\mathrm{Fe} 2 \mathrm{O} 3$ & 2.95 & - \\
\hline $\mathrm{MgO}$ & 2.17 & $5 \% \operatorname{Max}$ \\
\hline $\mathrm{SO} 3$ & 2.18 & $2.5 \% \operatorname{Max}$ \\
\hline Loss on Ignition (L.O.I) & 1.24 & $4 \% \operatorname{Max}$ \\
\hline Insoluble Material & 0.44 & $1.5 \% \mathrm{Max}$ \\
\hline Lime Saturation Factor ( L.S.F ) & 0.87 & $(0.66-1.02)$ \\
\hline \multicolumn{3}{|c|}{ Main Compounds } \\
\hline C3S & 50.71 & - \\
\hline C2S & 21.7 & - \\
\hline C3A & 4.25 & $<5 \%$ \\
\hline C4AF & 9.065 & - \\
\hline
\end{tabular}




\subsection{Fine Aggregate}

The sand used in this experimental research was collected from Qara Salim / Kirkuk / Iraq. Sieve analysis was applied on the samples and the results are presented in Table 3. The chemical and physical properties of the fine aggregate are shown in Table 4.

\begin{tabular}{ccccc}
\hline Sieve size & Retained & $\begin{array}{c}\text { Cumulative } \\
\text { Passing (\%) }\end{array}$ & $\begin{array}{c}\text { Limit of Passing for IQS No.45\1984 for } \\
\text { zone 3 }\end{array}$ \\
\hline In (SSTM) & $\mathrm{mm}$ & & & $90-100$ \\
\hline No. 4 & 4,75 & 3 & 97 & $60-95$ \\
\hline No. 8 & 2,36 & 11 & 89 & $30-70$ \\
\hline No. 16 & 1.18 & 34 & 66 & $15-34$ \\
\hline No. 30 & 600 & 67 & 33 & $5-20$ \\
\hline No. 50 & 300 & 83 & 17 & $0-10$ \\
\hline No. 100 & 150 & 93 & 7 & \\
\hline
\end{tabular}

Table (4): Chemical and physical properties of fine aggregates

\begin{tabular}{cccc}
\hline Properties & Specification & Test Results & Limits of specification \\
\hline Specific Gravity & ASTM C128-01 & 2.425 & - \\
\hline Absorption \% & ASTM C128-01 & $1.18 \%$ & - \\
\hline Dry Loose Unit Weight, kg/m3 & ASTM C29/C29M/97 & 1789 & - \\
\hline $\begin{array}{c}\text { Sulfate Content } \\
\text { (as SO3) , \% }\end{array}$ & (I.Q.S.) No. 45-1984 & 0.054 & \\
\hline Material Finer than & & & 5 (max. value) \\
Sieve 0.075 $\mathrm{mm}$ & (I.Q.S.) No. 45-1984 & & \\
\hline
\end{tabular}

\subsection{Coarse Aggregate}

\subsubsection{Normal Coarse Aggregate}

Coarse aggregate is an essential material used in concrete, it takes the biggest portion of the mixture. Size of the crushed coarse aggregate can play a significant role in mixture workability, size of maximum coarse aggregate was about $12.5 \mathrm{~mm}$. washing the coarse aggregate to remove any suspended materials, such as dust, is an important process before mix the concrete. The results from the Kirkuk National laboratory tests are shown in Tables 5 and 6.

Table (5): Grading of normal coarse aggregate

\begin{tabular}{cccc}
\hline Sieve size & Cumulative Retained \% & Passing $\%$ & Limit of Passing for IQS No.45/1984 \\
\hline $20 \mathrm{~mm}$ & 0 & 100 & 100 \\
\hline $14 \mathrm{~mm}$ & 1.5 & 98.5 & $90-100$ \\
\hline $10 \mathrm{~mm}$ & 37 & 63 & $40-70$ \\
\hline $5 \mathrm{~mm}$ & 97.25 & 2.75 & $0-15$ \\
\hline $2.36 \mathrm{~mm}$ & 99.02 & 0.98 & $0-5$ \\
\hline
\end{tabular}

baraakamel@uokirkuk.edu.iq; muyasserjomaah@tu.edu.iq; dr.husamdaham@tu.edu.iq 
Table (6): Chemical and physical properties of normal coarse aggregates

\begin{tabular}{|c|c|c|c|}
\hline Properties & Specification & $\begin{array}{c}\text { Test } \\
\text { Results }\end{array}$ & Limits of specification \\
\hline Specific Gravity & ASTM C128-01 & 2.49 & - \\
\hline Absorption (\%) & ASTM C128-01 & 1.15 & - \\
\hline $\begin{array}{l}\text { Dry Loose Unit Weight } \\
\qquad \mathrm{kg} / \mathrm{m} 3\end{array}$ & ASTM C29/C29M/97 & 1598 & - \\
\hline $\begin{array}{l}\text { Sulfate Content } \\
\text { (as SO3) (\%) }\end{array}$ & (I.Q.S.) No. 45-84 & 0.031 & 0.1 (max. value) \\
\hline
\end{tabular}

\subsubsection{Claystone Coarse Aggregate}

Claystone, or Ponza shown in Fig. (1), is the type of lightweight aggregate that used in the mixtures as a coarse aggregate. Maximum nominal size of the claystone was $12.5 \mathrm{~mm}$, different ratios of replacing the normal coarse aggregate were applied to study the effect of lightweight aggregate on the behavior of concrete. The volumetric ratios 25,50 , and 75 percentages were chosen to represent the variety of the lightweight. Lightweight aggregate gradation is shown in Table 7 which represent the percentage of the weight passing through the sieve. The results demonstrate that the samples achieved the American standard ASTM C330. (2005). Table 8 and Table 9 show the physical and chemical properties of the lightweight coarse aggregate (Ponza) respectively, the chemical tests were completed in the Quality Control Laboratories / Cement Mass Company / Sulaymaniyah, while the gradiation and physical tests were conducted at Kirkuk National Laboratory.

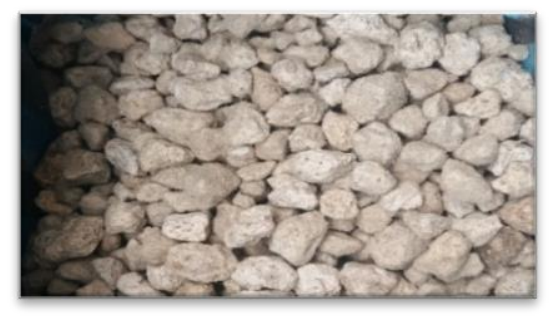

Fig. (1): Lightweight claystone coarse aggregate

Table (7): Gradation test of lightweight claystone coarse aggregate

\begin{tabular}{ccc}
\hline Sieve Size & Cumulative Passing \% & Limit of ASTM C330-99 \\
\hline $12.5-\mathrm{mm}$ & 93.6 & $90-100$ \\
\hline $9.5-\mathrm{mm}$ & 60.3 & $40-80$ \\
\hline $4.75-\mathrm{mm}$ & 12.7 & $0-20$ \\
\hline
\end{tabular}

baraakamel@uokirkuk.edu.iq; muyasserjomaah@tu.edu.iq; dr.husamdaham@tu.edu.iq ${ }^{2}$ Corresponding author: College of Engineering, University of Tikrit, Tikrit, Iraq 
Table (8): Physical properties of lightweight claystone coarse aggregate

\begin{tabular}{cccc}
\hline Properties & Specification & Test Results & Limits of specification \\
\hline Specific Gravity & ASTM C127-88 & 1.385 & - \\
\hline Absorption \% & ASTM C127-88 & 4.55 & - \\
\hline Dry Loose Unit Weight, kg/m3 & ASTM C29/C29M/97 & 626 & - \\
\hline Sulfate Content (as SO3), \% & BS 3797-part 2-1981 & 0.125 & 1.0 (max. value) \\
\hline
\end{tabular}

Table (9): Chemical analysis of lightweight claystone coarse aggregate

\begin{tabular}{cc}
\hline Oxides & \% by Weight \\
\hline $\mathrm{SiO} 2$ & 66.41 \\
\hline $\mathrm{CaO}$ & 4.29 \\
\hline $\mathrm{MgO}$ & 1.94 \\
\hline $\mathrm{SO} 3$ & 0.1 \\
\hline $\mathrm{Al2O} 3$ & 15.85 \\
\hline $\mathrm{Fe} 2 \mathrm{O} 3$ & 2.87 \\
\hline $\mathrm{K} 2 \mathrm{O}$ & 1.92 \\
\hline $\mathrm{Na2O}$ & 2.2 \\
\hline L.O.I & 4.26 \\
\hline Total & 99.84
\end{tabular}

\subsubsection{Thermostone Coarse Aggregate}

Waste crushed thermostone was adopted as coarse aggregate in this research. The source of this type of aggregate was a building under construction and the thermostone was cut and sieved with maximum size of $12.5 \mathrm{~mm}$ Fig (2), thermostone aggregate replacement ratios used in this research were 25, 50 and 75 percentage of the normal coarse aggregates, this type of aggregate is put in water for at least one day before it can be used in a dry saturated condition, so it would not absorb the mixing water and reduce the strength of the concrete. The gradation results are good, and it is in accordance with ASTM (1999), as shown in
Table 10. Tables 11 and 12 show the physical properties and chemical analysis of the lightweight crushed thermostone coarse aggregate. The tests were done in the Quality Control Laboratories / Cement Mass Company / Sulaymaniyah and Kirkuk National Laboratory.

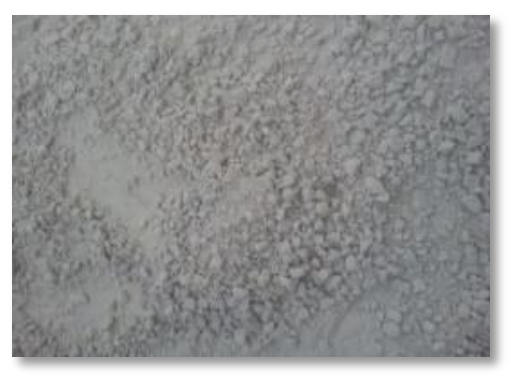

Fig. (2): Thermostone aggregate

Table (10): Gradation for lightweight crushed coarse thermostone aggregate

\begin{tabular}{ccc}
\hline Sieve Size & Cumulative Passing \% & Limit of ASTM C330-99 \\
\hline $12.5-\mathrm{mm}$ & 95.2 & $90-100$ \\
\hline $9.5-\mathrm{mm}$ & 71.34 & $40-80$ \\
\hline $4.75-\mathrm{mm}$ & 17.3 & $0-20$ \\
\hline
\end{tabular}

baraakamel@uokirkuk.edu.iq; muyasserjomaah@tu.edu.iq; dr.husamdaham@tu.edu.iq 
Journal of University of Duhok, Vol. 23, No.2 (Pure and Eng. Sciences), Pp 601-616, 2020 (Special Issue)

$3^{\text {rd }}$ international conference on recent innovations in engineering (ICRIE) Duhok, September 9-10-2020

Table (11): Chemical and physical properties of lightweight crushed coarse thermostone aggregate

\begin{tabular}{cccc}
\hline Properties & Specification & Test Results & Limits of specification \\
\hline Specific Gravity & ASTM C127-88 & 1.25 & - \\
\hline Absorption \% & ASTM C127-88 & 45 & - \\
\hline Dry Loose Unit weight, $\mathrm{kg} / \mathrm{m3}$ & ASTM C29/C29M/97 & 450 & - \\
\hline Sulfate Content (as SO3), \% & BS 3797-part 2-1981 & 0.3 & 1(max.value) \\
\hline
\end{tabular}

Table (12): Chemical analysis of thermostone aggregate lightweight crushed coarse thermostone

\begin{tabular}{cc}
\multicolumn{2}{c}{ aggregate } \\
\hline Oxides & \% by Weight \\
\hline $\mathrm{SiO} 2$ & 46.42 \\
\hline $\mathrm{CaO}$ & 38.44 \\
\hline $\mathrm{MgO}$ & 3.46 \\
\hline $\mathrm{SO} 3$ & 0.3 \\
\hline $\mathrm{Al} 2 \mathrm{O} 3$ & 3.37 \\
\hline Fe2O3 & 3.18 \\
\hline L.O.I & 4.5 \\
\hline Total & 99.67
\end{tabular}

\subsubsection{Polystyrene}

Polystyrene, shown in Fig. (3) is an inexpensive polymer, type used in this study is medium density of non- compressed cork granules, the reason that the Polyisoprene used in this work was to control the volumetric replacement.

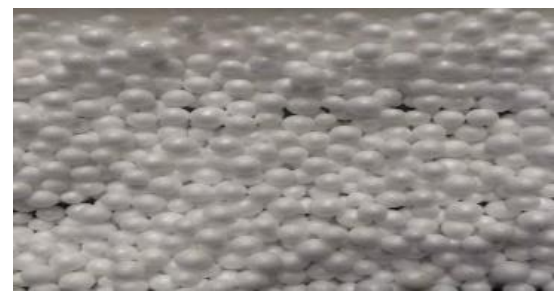

Fig. (3): Polystyrene (or Cork)

\subsubsection{Rubber}

This material is affordable and could be used in many application fields such as constructions, recycled rubber from automotive tire was selected to work as a normal crushed stone in this paper, it was cut into small pieces Fig. (4).

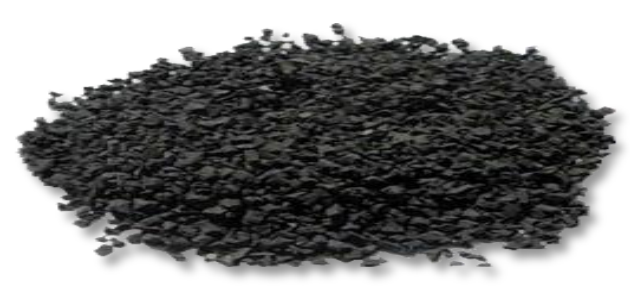

Fig. (4): Rubber from waste tires used

\subsection{Water Mixing}

Clean water from Kirkuk city water supply network was added to the concrete mixture. The $\mathrm{pH}$ test showed that the water was 7.6 according to IQS. The water used in curing the concrete was also from Kirkuk city water supply network [7].

\section{Mixing Proportions}

Many samples of concrete were casted, Table 13. Six concrete cubes for each mixture of different water content (W/C). The results of slump test demonstrated that the precipitation ranged from (25) to $(75) \mathrm{mm}$. The mixture was designed using ACI (1991) (1: 1.5: 3). The

baraakamel@uokirkuk.edu.iq; muyasserjomaah@tu.edu.iq; dr.husamdaham@tu.edu.iq ${ }^{2}$ Corresponding author: College of Engineering, University of Tikrit, Tikrit, Iraq 
concrete cube strengths were measured at age 28 days. The dimensions of the concrete cubes were of standard dimensions $(150 \times 150 \times 150 \mathrm{~mm})$ and the static loading rate was $(0.3 \mathrm{kN} / \mathrm{Sec})$. The concrete mix of (1: 1.31: 1.79) was selected with cement content of $(490 \mathrm{~kg} / \mathrm{m} 3)$. The highest compressive strength of $(47 \mathrm{~N} / \mathrm{mm} 2)$ was recorded.

Table (13): Summarized the concrete mixtures and results obtained from tests

\begin{tabular}{ccccccc}
\hline Trail Mix & $\begin{array}{c}\text { Cement } \\
\text { Content(kg/m })\end{array}$ & WC & Mix Proportion & $\begin{array}{c}\text { Av } \\
\text { density } \\
\mathbf{k g} / \mathbf{m}^{3}\end{array}$ & $\begin{array}{c}\text { Compressive } \\
\text { strength } \mathbf{N} / \mathbf{m m}^{2}\end{array}$ & $\begin{array}{c}\text { Slump 25 - } \\
\mathbf{7 5 m}\end{array}$ \\
\hline 1 & 400 & 0.38 & $1: 1.5: 3$ & 2408 & 55.4 & 18 \\
\hline 2 & 400 & 0.40 & $1: 1.5: 3$ & 2400 & 44.6 & 44 \\
\hline 3 & 400 & 0.42 & $1: 1.5: 3$ & 2400 & 43.6 & 51 \\
\hline 4 & 425 & 0.38 & $1: 1.5: 3$ & 2400 & 42 & 47 \\
\hline 5 & 425 & 0.40 & $1: 1.5: 3$ & 2367 & 33.6 & 65 \\
\hline 6 & 425 & 0.42 & $1: 1.5: 3$ & 2400 & 34.4 & 60 \\
\hline 7 & 450 & 0.38 & $1: 1.5: 3$ & 2400 & 36.1 & 58 \\
\hline 8 & 450 & 0.40 & $1: 1.5: 3$ & 2400 & 42.3 & 50 \\
\hline 9 & 450 & 0.42 & $1: 1.5: 3$ & 2403 & 46.6 & 54 \\
\hline 10 & 490 & 0.42 & $1: 1.31: 1.79$ & 2393 & 47 & 52 \\
\hline
\end{tabular}

\section{EXPERIMENTAL WORK}

The best trial mixture was chosen after analyzed all the available data, the concrete mixtures had been prepared in various proportions of volumetric replacement of coarse aggregates with lightweight coarse aggregates (Ponza stone, crushed thermostone, polystyrene and rubber), these proportions were 25,50 and 75 percentages, afterward, the effect of replacement of the normal course of aggregate with the crushed lightweight aggregate was studied. The physical and mechanical properties of the mixture were considered, three cylindrical concrete specimens with dimensions of $(150 \times 300) \mathrm{mm}$ were cast for each replacement ratio. In addition, three samples with $(300 \times 150)$ $\mathrm{mm}$ dimensions were carried out to calculate the splitting tensile strength and additional three cylindrical specimens to measure the concrete density. Moreover, three prism samples with dimensions of $(500 \times 100 \times 100) \mathrm{mm}$ to calculate the modules of rapture. Fig. (5) shows test setup and concrete formwork. A test matrix is listed in Table 14.

baraakamel@uokirkuk.edu.iq; muyasserjomaah@tu.edu.iq; dr.husamdaham@tu.edu.iq ${ }^{2}$ Corresponding author: College of Engineering, University of Tikrit, Tikrit, Iraq 

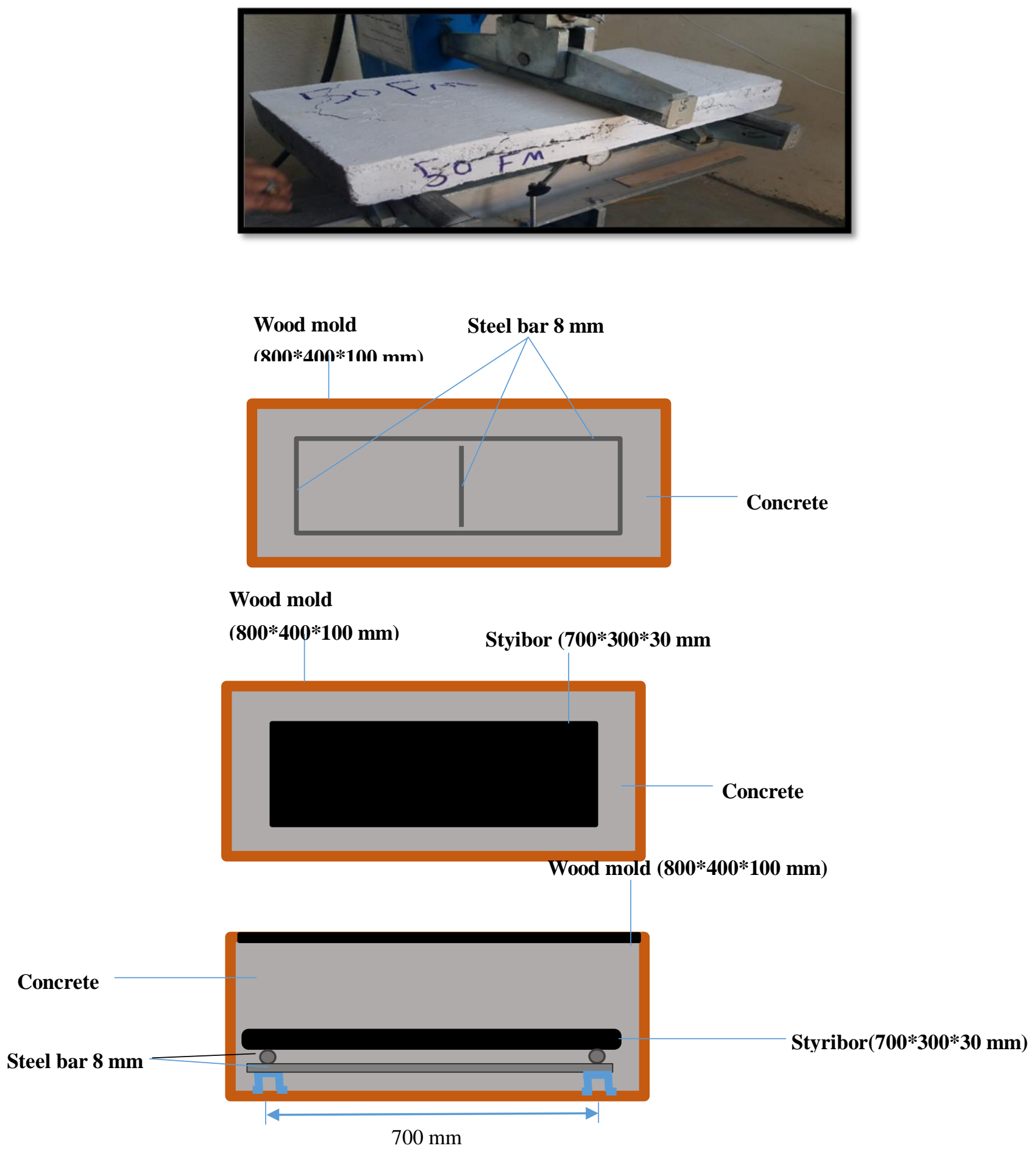

Fig. (5): Test setup and formwork

baraakamel@uokirkuk.edu.iq; muyasserjomaah@tu.edu.iq; dr.husamdaham@tu.edu.iq ${ }^{2}$ Corresponding author: College of Engineering, University of Tikrit, Tikrit, Iraq 
Table (14): Test matrix

\begin{tabular}{|c|c|c|c|c|c|}
\hline Mix. No. & $\begin{array}{c}\text { Clay stone } \\
\text { Coarse Agg. \% }\end{array}$ & Rubber\% & $\begin{array}{c}\text { Thermo } \\
\text { stone Coarse } \\
\text { Agg } \%\end{array}$ & $\begin{array}{c}\text { Poly styrene } \\
\%\end{array}$ & $\begin{array}{c}\text { Number of } \\
\text { Samples }\end{array}$ \\
\hline MR1 & 0 & 0 & 0 & 0 & 3 \\
\hline M2 & 25 & 0 & 0 & 0 & 3 \\
\hline M3 & 50 & 0 & 0 & 0 & 3 \\
\hline M4 & 75 & 0 & 0 & 0 & 3 \\
\hline M5 & 0 & 25 & 0 & 0 & 3 \\
\hline M6 & 0 & 50 & 0 & 0 & 3 \\
\hline M7 & 0 & 75 & 0 & 0 & 3 \\
\hline M8 & 0 & 0 & 25 & 0 & 3 \\
\hline M9 & 0 & 0 & 50 & 0 & 3 \\
\hline M10 & 0 & 0 & 75 & 0 & 3 \\
\hline M11 & 0 & 0 & 0 & 25 & 3 \\
\hline M12 & 0 & 0 & 0 & 50 & 3 \\
\hline M13 & 0 & 0 & 0 & 75 & 3 \\
\hline
\end{tabular}

\section{RESULTS AND DISCUSSION}

\subsection{Flexural behavior}

There are at least four distinct phases in the behavior of a slab that is loaded until its failure point. The first phase is the behavior of the slab before cracking. In this stage, the performance of the slab is same as to an elastic plate. Therefore, the deformations, stresses and strains can be estimated from an elastic analysis. The second phase starts after first cracks appears; however, it is before the yield stress of the steel reinforcement, in the second stage, the slab stiffness is no longer acting as constant stiffness because the cracks reduce the flexural stiffness EI. The third phase begins when the steel reinforcement starts to yield in one or more area under high moment, in this stage, the stress within the slab redistributes from the area of high stress to the one that still elastic. The last phase is when the loads increase and the yield lines work to divide the slab. In this last stage, large deflection can occur. In this study, observing first cracks was determined and recorded against the loads as presented in Table

baraakamel@uokirkuk.edu.iq; muyasserjomaah@tu.edu.iq; dr.husamdaham@tu.edu.iq ${ }^{2}$ Corresponding author: College of Engineering, University of Tikrit, Tikrit, Iraq 
15. Obviously, samples with the rubber lightweight aggregate behaved better than other types of hollow slabs, the initial cracks of the specimens made from rubber aggregates were delayed due to the tensile strength of the rubber. In addition, the lowest load observed to cause first cracks was $7 \mathrm{kN}$ and it was recorded in the samples with thermostone aggregate, in general, increasing the replacement ratio of lightweight aggregate in concrete mixture leads to appearing initial cracks at lower loads for all specimens. Moreover, the ultimate load up to failure point of the hollow slabs was also considered in this research as a main parameter. Clearly, from the results demonstrated in Table 15, the hollow slabs that have maximum measured failure loads sorted by materials from the biggest to lowest value were claystone, rubber, thermostone and polystyrene slabs, respectively.

Table (15): Results of the flexural strength of the hollow slab

\begin{tabular}{|c|c|c|c|c|}
\hline Mix. No. & $\begin{array}{l}\text { First Crack Load } \\
\qquad(\mathrm{kN})\end{array}$ & $\begin{array}{l}\text { Failure Load } \\
\text { Average } \\
(\mathrm{Pu}),(\mathrm{kN})\end{array}$ & $\begin{array}{c}\text { Failure Load } \\
\text { Decreasing (\%) }\end{array}$ & $\begin{array}{r}\left(\delta_{u}\right) \\
(\mathrm{mm})\end{array}$ \\
\hline MR1 & 16 & 24.810 & - & 10 \\
\hline M2 & 10 & 23.704 & 12.01 & 8 \\
\hline M3 & 12 & 20.304 & 24.63 & 8 \\
\hline M4 & 9 & 19.670 & 26.98 & 8 \\
\hline M5 & 13 & 20.305 & 24.62 & 5 \\
\hline M6 & 12 & 20.256 & 24.81 & 5 \\
\hline M7 & 12 & 19.650 & 27.06 & 6 \\
\hline M8 & 7 & 18.043 & 33.02 & 5 \\
\hline M9 & 11 & 16.195 & 39.88 & 7 \\
\hline M10 & 11 & 15.311 & 43.16 & 5 \\
\hline M11 & 12 & 15.081 & 44.02 & 5 \\
\hline M12 & 9 & 14.090 & 47.69 & 5 \\
\hline M13 & 7 & 9.259 & 65.63 & 4 \\
\hline
\end{tabular}

\subsection{Ultimate Load and Deflection}

One dial gauge was located at the center of the hollow slab in both directions to measure the mid slab deflection. The loads were recorded during the test. The relationship between the loads and the deflections was plotted Fig. (6,7,8 and 9), some jumped points observed in the graphs were due to the machine test error. The failure mode observed in the slab tests was flexural failure, the curves in Fig(6), which represent comparison between the reference slab and the others with 25,50 and 75 percentage of claystone aggregate ratios, demonstrated that the ultimate loads of the tested slabs reduced with increased the claystone ratios in the mixture. This degradation reached its maximum value at $12 \mathrm{~mm}$ deflection and it was about 30 percentages for the slab with $75 \%$ of claystone aggregate ratio. The degradation of the samples with rubber aggregate was slightly more than the

baraakamel@uokirkuk.edu.iq; muyasserjomaah@tu.edu.iq; dr.husamdaham@tu.edu.iq ${ }^{2}$ Corresponding author: College of Engineering, University of Tikrit, Tikrit, Iraq 
value of the samples with claystone aggregate and it recorded approximately 40 percentages. This is not the case with using thermostone and polystyrene as coarse aggregates in which the ultimate loads measured at lower deflections compared with claystone and rubber. Moreover, degradation of the maximum loads was also observed in the hollow slabs made from these two types of aggregate specially slabs with polystyrene. Fig. (10, a,b and c) shows the cracks appeared in the hollow slabs for different replacement ratios of various types aggregates used in this study. Clearly from Fig (10), the hollow slabs made from claystone aggregate have the highest cracks within the slabs, in addition, the hollow slabs made from rubber aggregate at high ratio, $75 \%$, have less cracks at the mid-span of the slabs.

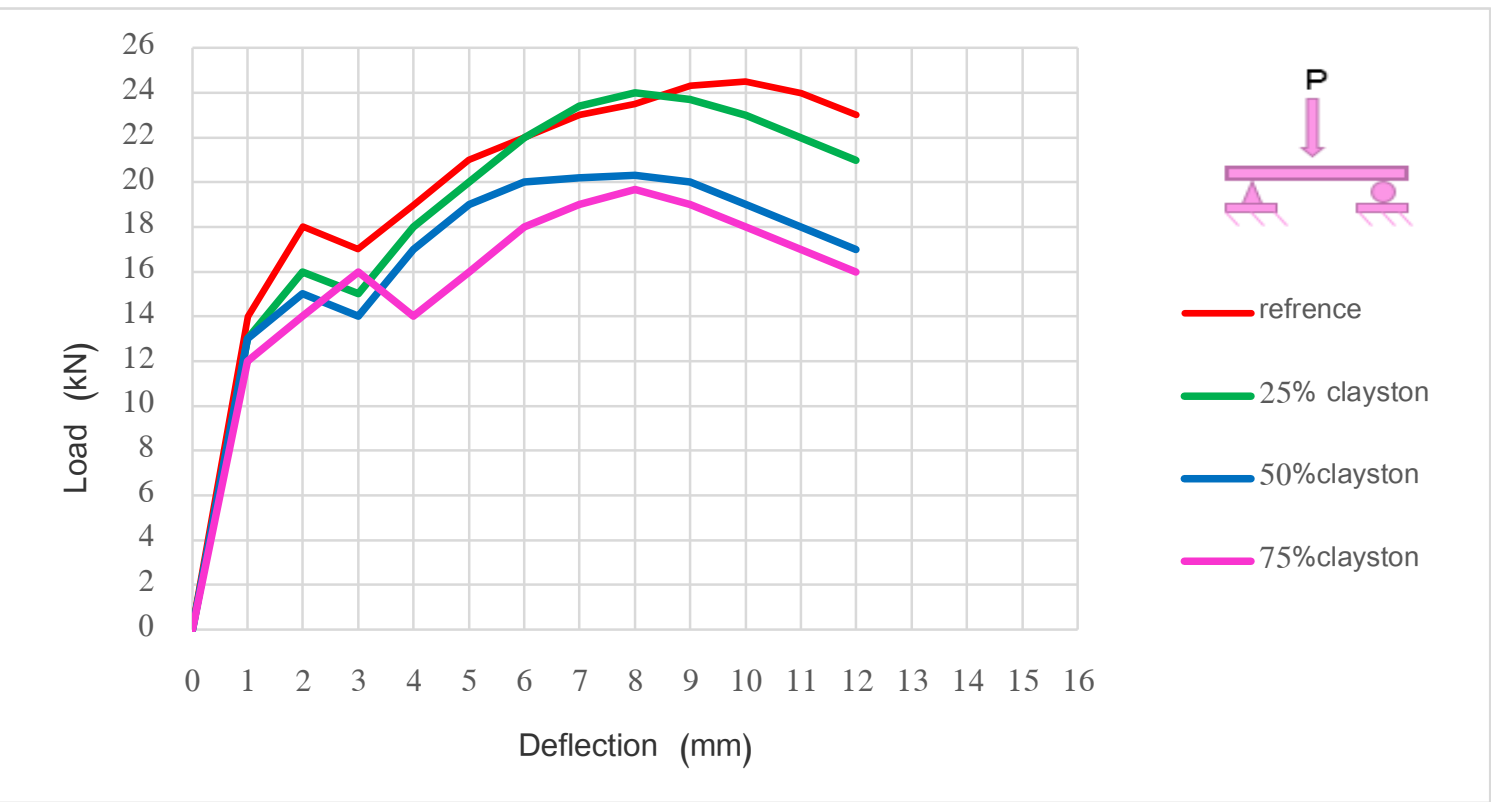

Fig. (6): Load-Deflection graph for hollow slab samples made from claystone aggregate

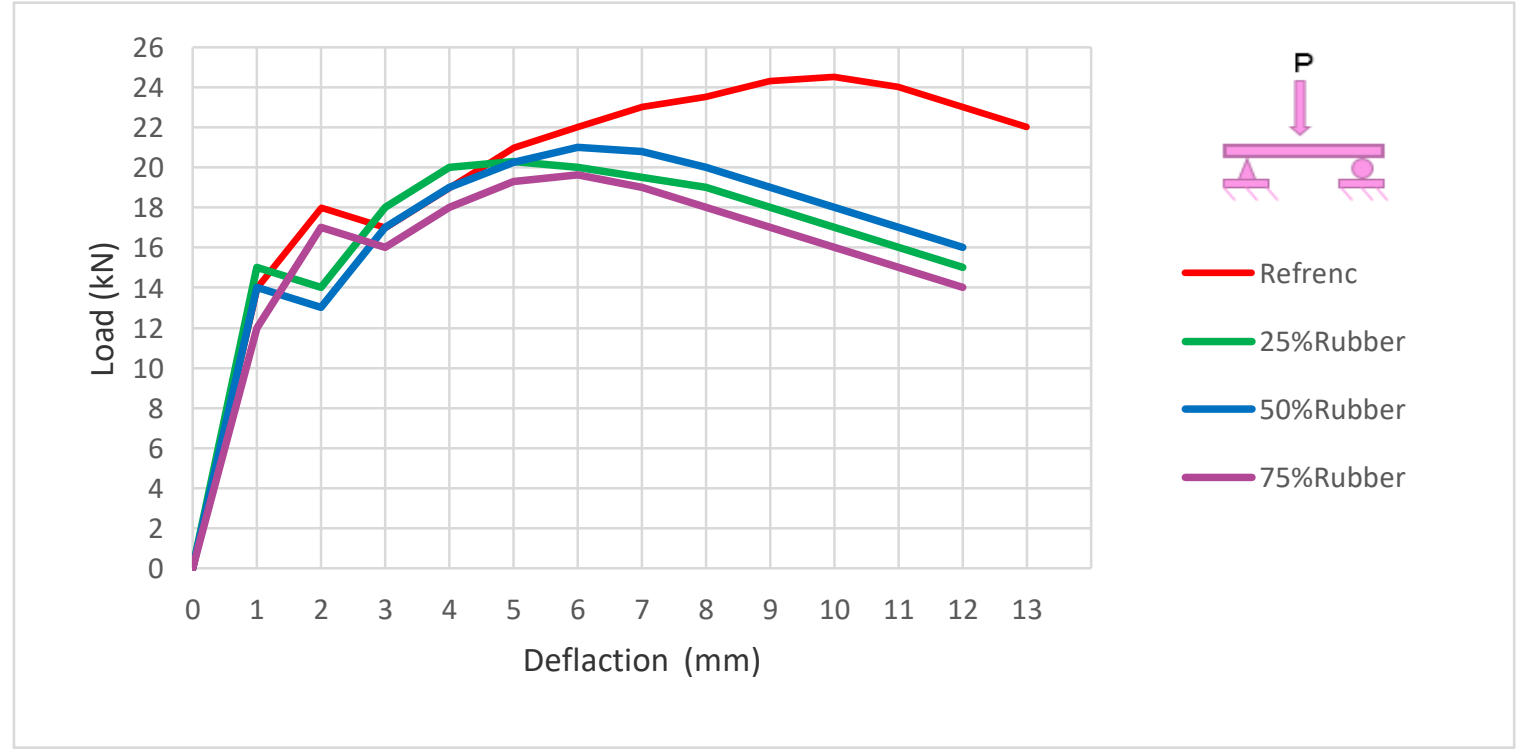

Fig. (7): Load-Deflection graph for hollow slab samples made from rubber aggregate

baraakamel@uokirkuk.edu.iq; muyasserjomaah@tu.edu.iq; dr.husamdaham@tu.edu.iq 


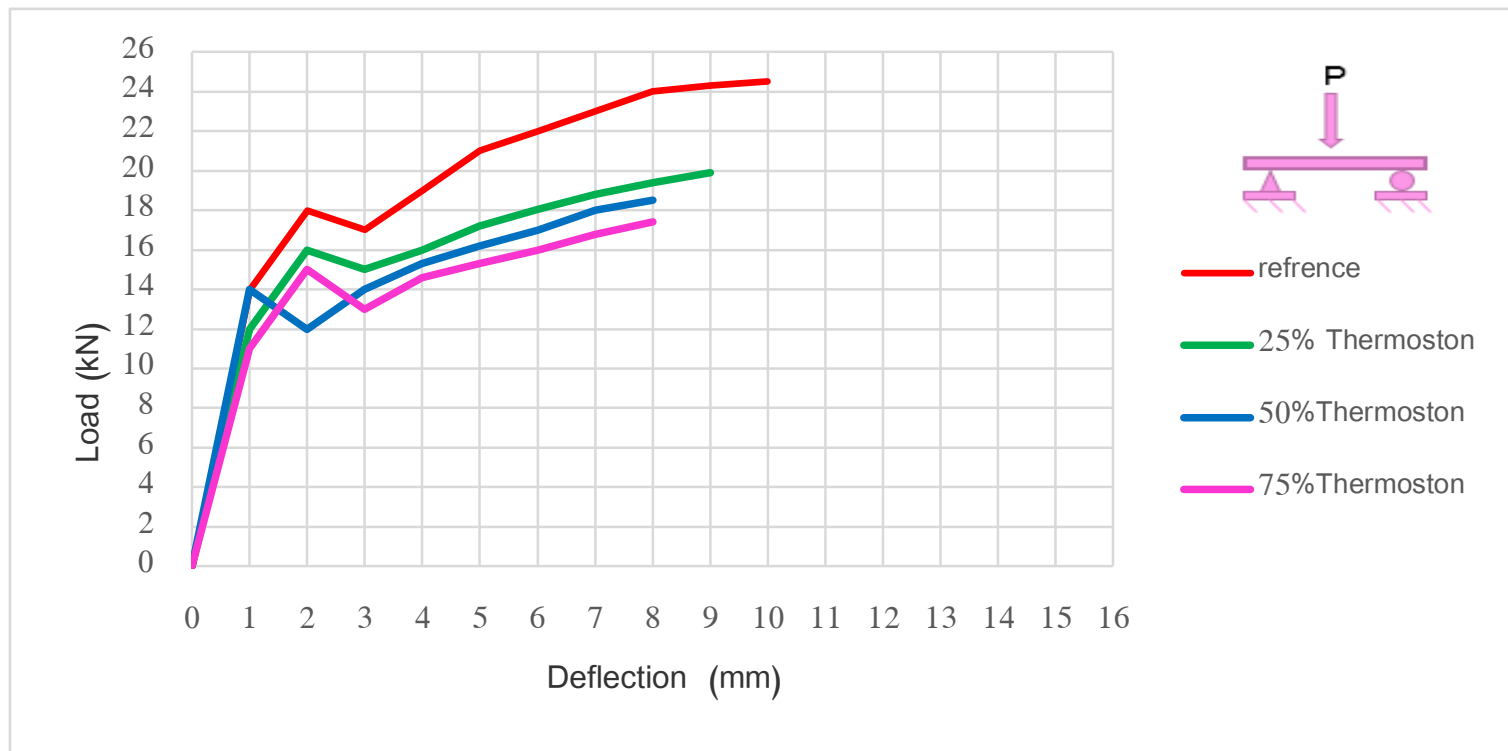

Fig. (8): Load-Deflection graph for hollow slab samples made from thermostone aggregate

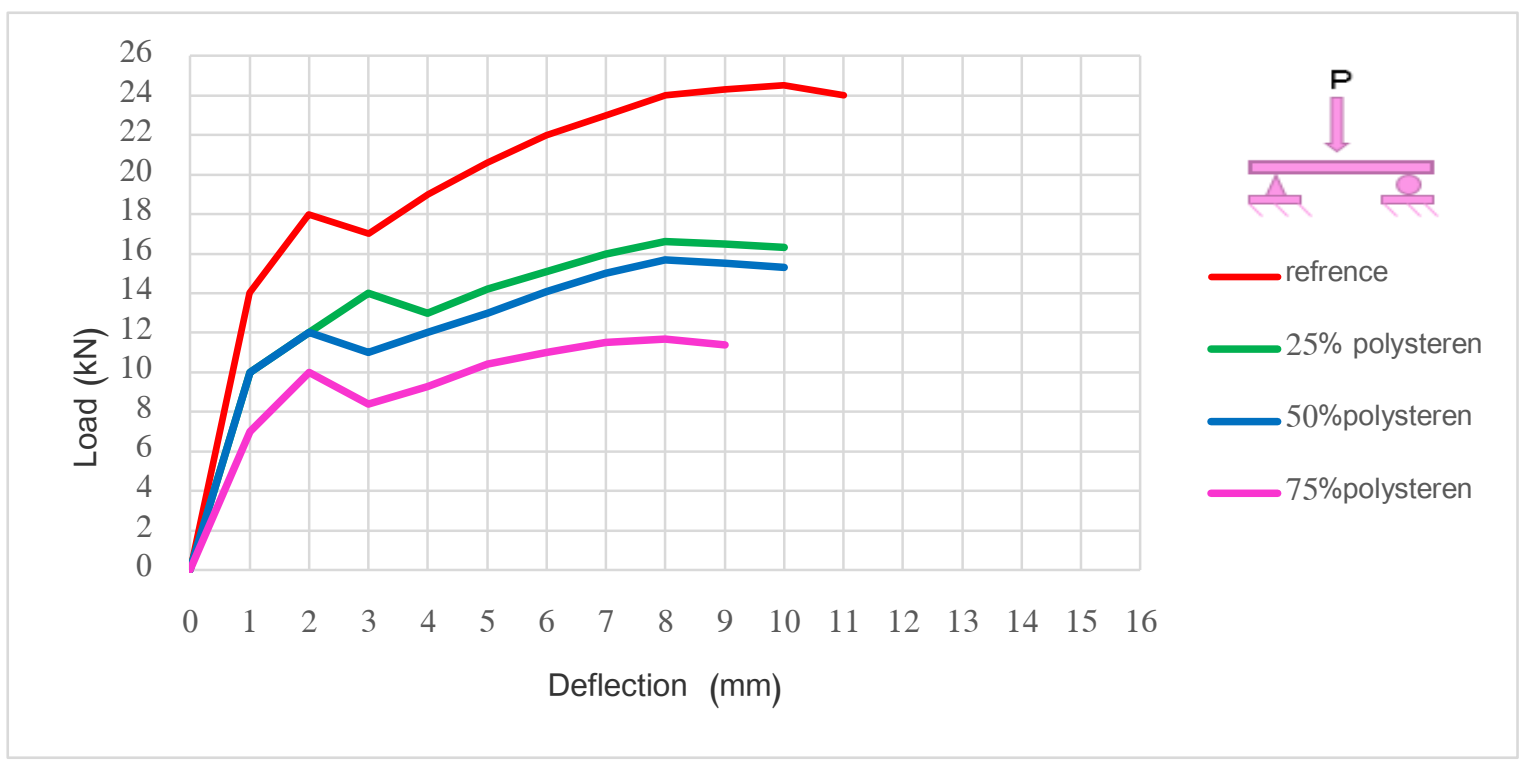

Fig. (9): Load-Deflection Graph for Hollow Slab Samples Made from polysteren aggregate

baraakamel@uokirkuk.edu.iq; muyasserjomaah@tu.edu.iq; dr.husamdaham@tu.edu.iq ${ }^{2}$ Corresponding author: College of Engineering, University of Tikrit, Tikrit, Iraq 


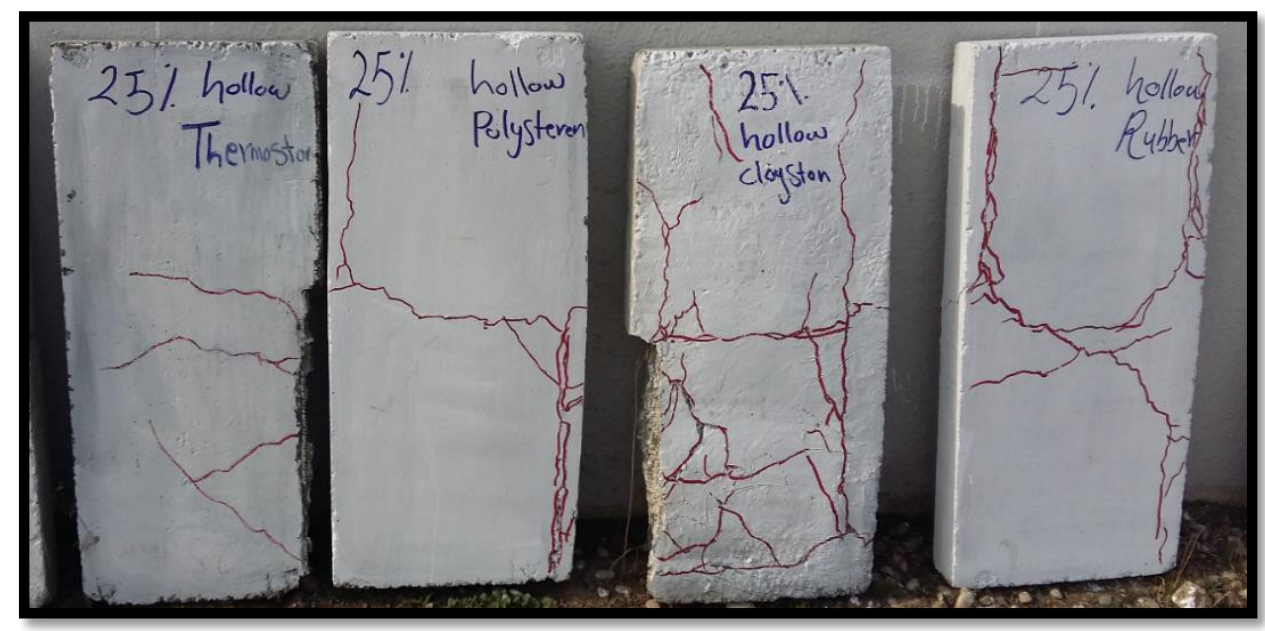

A - Hollow slabs at the replacement ratio of $25 \%$

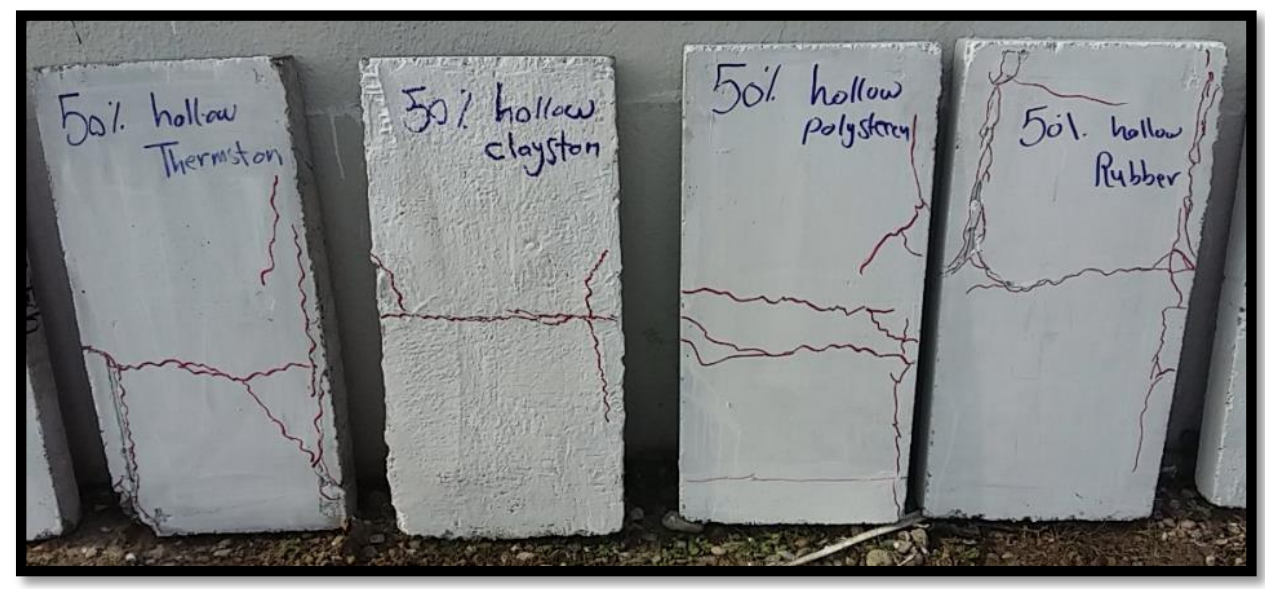

B - Hollow slabs at the replacement ratio of $50 \%$

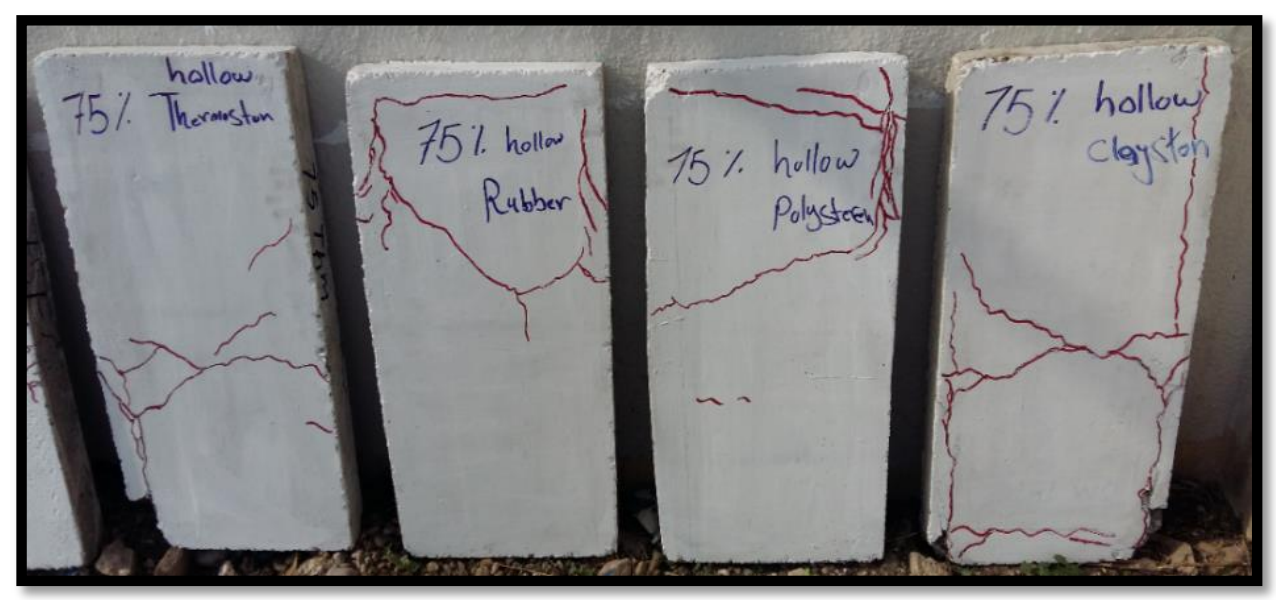

C- Hollow slabs at the replacement ratio of $75 \%$

Fig. (10): Modes of failure in solid and hollow concrete slabs

baraakamel@uokirkuk.edu.iq; muyasserjomaah@tu.edu.iq; dr.husamdaham@tu.edu.iq 


\subsection{Ductility index}

Ductility index is the ratio of the total deformation at ultimate load to the elastic limit deformation. It can also define as the total energy to the elastic energy at the failure stage. Larger ductility index refers to better performance of the component. It can be calculated based on a simple linear equation.

$\mu \Delta=\Delta u / \Delta y$

$\mu \Delta=$ ductility index
$\Delta \mathrm{u}=$ maximum deflection at failure

$\Delta \mathrm{u}=$ deflection at yield point

The ductility index is shown in Table 16 for all the slabs tested in this research. As can be seen, the claystone hollow slabs have the highest ductility index compared with the other slabs. The reason for this behavior is that the ultimate deflection of the hollow slab with claystone is much more than others.

Table (16): Ductility index for the hollow reinforced concrete slabs.

\begin{tabular}{|c|c|c|c|c|}
\hline \multirow[t]{2}{*}{ Group No. } & \multirow[t]{2}{*}{$\begin{array}{c}\text { Replacement samples } \\
\%\end{array}$} & \multicolumn{3}{|c|}{ For Hollow Slab } \\
\hline & & $\begin{array}{l}\text { Deflections at First Cracking } \\
\text { Load } \\
\left(\boldsymbol{\delta}_{\boldsymbol{y}}\right) \mathrm{mm}\end{array}$ & $\begin{array}{l}\text { Failure Load Deflections } \\
\qquad\left(\boldsymbol{\delta}_{\boldsymbol{u}}\right) \mathrm{mm}\end{array}$ & $\begin{array}{c}\text { Ductility index } \\
\left(\boldsymbol{\mu}_{\Delta=\delta_{u} / \delta_{y}}\right)\end{array}$ \\
\hline MR1 & Reference & 3 & 10 & 3.33 \\
\hline M2 & $25 \%$ clayston & 3 & 9 & 3 \\
\hline M3 & $50 \%$ clayston & 3 & 8 & 2.66 \\
\hline M4 & $75 \%$ clayston & 4 & 8 & 2 \\
\hline M5 & $25 \%$ Rubber & 2 & 5 & 2.5 \\
\hline M6 & $50 \%$ Rubber & 2.2 & 5 & 2.25 \\
\hline M7 & $75 \%$ Rubber & 3.1 & 6 & 1.93 \\
\hline M8 & $25 \%$ Thermoston & 3 & 6 & 2 \\
\hline M9 & $50 \%$ Thermoston & 2.7 & 5 & 1.85 \\
\hline M10 & 75\% Thermoston & 2.8 & 5 & 1.75 \\
\hline M11 & $25 \%$ Polystyren & 3.5 & 6 & 1.71 \\
\hline M12 & $50 \%$ polystyren & 3 & 5 & 1.66 \\
\hline M13 & $75 \%$ polystyren & 3.1 & 5 & 1.61 \\
\hline
\end{tabular}

baraakamel@uokirkuk.edu.iq; muyasserjomaah@tu.edu.iq; dr.husamdaham@tu.edu.iq ${ }^{2}$ Corresponding author: College of Engineering, University of Tikrit, Tikrit, Iraq 


\section{CONCLUSIONS}

This study represents ongoing research on using the lightweight aggregate in structural field at Tikrit University, the first published paper (Jomaa'h et al. 2019) has in details all the information about the concrete hardened described in the present paper. Based on the experimental results obtained from present study, the following main conclusions can be summarized

1- Flexural failure mode is the type of failure observed in all types of the hollow slabs used in the present study.

2- Flexural capacity of lightweight aggregate hollow slabs is less than that of the hollow slabs made from normal aggregate.

3- Initial cracks of the hollow slabs made from rubber lightweight aggregate were delayed compared with other types of aggregated due to high tensile strength of the rubber particles.

4- Failure load deflections of the slabs included in the present study reduce by increasing the replacement ratio except samples with rubber aggregate due to high ductility of the rubber.

5 - The highest ductility index was observed in the hollow slabs made from claystone aggregate due to higher deflection at failure loads.

\section{REFERENCES}

ACI Committee-211. (1991). Standard practice for selecting proportions for normal, heavyweight and mass concrete. American Concrete Institute Committee: Farmington Hills, MI, USA.

ACI Committee-213. (2003). Guide for structural lightweight aggregate concrete. American Concrete Institute Committee: Farmington Hills, MI, USA.

ACI Committee-314R. (2011). Guide to Simplified Design for Reinforced Concrete Building. American Concrete Institute Committee: Farmington Hills, MI, USA.
ACI Committee-318. (2008). Building Code Requirements for Structural Concrete and Commentary. American Concrete Institute Committee: Farmington Hills, MI, USA.

Al-Azzawi, A. A. (2017). "Behavior of Lightweight Coarse Aggregate RC Beams with Circular Opening, American Journal of Applied Sciences.

Al-mamoori, F. H. (2018). Production of Structural Light-Weight Aggregate Concrete Using Different Types of Iraqi Local Crushed Materials as Coarse Aggregate. Journal of University of Babylon, 26(1), 375-362.

ASTM C78-02. (2010). Standard Test Method for Flexural Strength of Concrete (Using Simple Beam with Third-Point Loading ). American Society for Testing and Materials, Annual Book, Pennsylvania, USA.

ASTM C330. (2005). Standard Specification for Lightweight Aggregates for Structural Concrete. American Society for Testing and Materials, Annual Book, Pennsylvania, USA, 04-02: 187-189.

Amato, G., Campione, G., Cavaleri, L., Minafò, G., Miraglia, N., (2011). The use of pumice lightweight concrete for masonry applications. Materials and Structures.

Iraqi Organization of Standards, IOS 5: 1984, for Portland cement (In Arabic).

Jomaa'h, M. M., Kamil, B. T. and Baghabra, O. S. (2019). Mechanical and Structural Properties of a Lightweight Concrete with Different Types of Recycling Coarse Aggregate. Tikrit Journal of Engineering Sciences, 26(1), 33-40.

Narayanan, N. and Ramamurthy, K. (2000). Structure and properties of aerated concrete: a review. Cement and Concrete Composites, 22, 321-329.

Walraven, J., (2002). "Self-Compacting Concrete in the Netherlands", Proceedings of the First North American Conference on the Design and Use of Self-Consolidating Concrete, Evanston, USA, pp. 355-360.

baraakamel@uokirkuk.edu.iq; muyasserjomaah@tu.edu.iq; dr.husamdaham@tu.edu.iq 